\title{
Historein
}

Vol 7 (2007)

History and Utopia

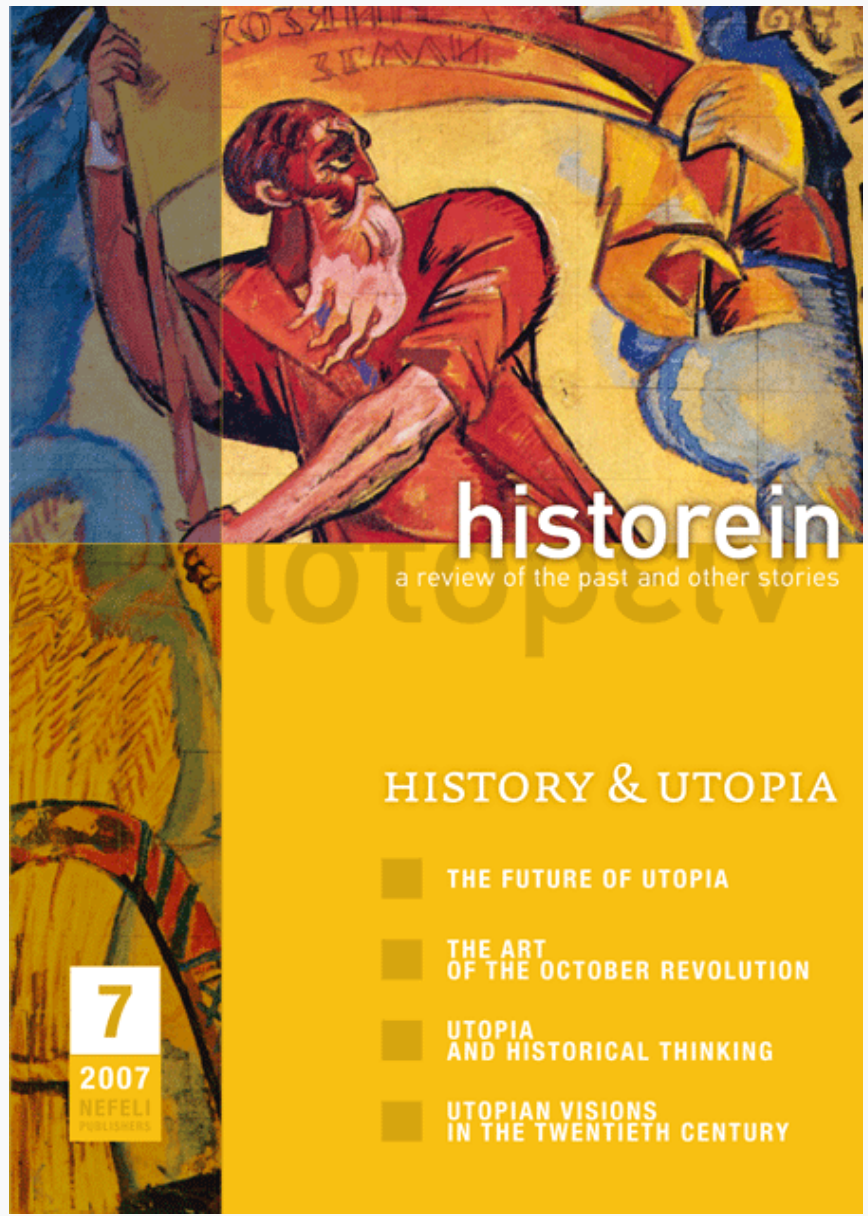

\section{A Successful Utopia: The Doctrine of Human Dignity}

Antoon De Baets

doi: $10.12681 /$ historein.51

Copyright $\odot$ 2012, Antoon De Baets

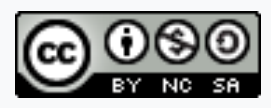

This work is licensed under a Creative Commons Attribution-NonCommercialShareAlike 4.0.

\section{To cite this article:}

De Baets, A. (2008). A Successful Utopia: The Doctrine of Human Dignity. Historein, 7, 71-85. https://doi.org/10.12681/historein.51 

It is likewise mentioned in the 1945 United Nations Charter, the preamble of the two 1966 Covenants emanating from the Universal Dedaration, and virtually all human-rights declarations, conventions, and international court statutes. In addition, three-quarters of the constitutions of the world's 193 states use the concepts of "human dignity" or "personal dignity" explicitly. ${ }^{3}$ Even constitutions using it implyitstrongly. What is true for dignity is also true for its opposite, indignity. 'Outrages upon personal dignity" are explicitly prohibited bythe Geneva Conventions and the International Criminal Court. The concept of dignity is increasingly used in legal argument and political discourse. And of course, human dignity is central to all major religious traditions and ethical systems when they speak about the sacred nature of human life.

The post-war success of the dignity concept is related to two factors, both referring to the fear of indignity. ${ }^{4}$ First, when people became aware of the horrors of the Holocaust, this triggered an international outcry. These horrors were seen as violations of human dignity. A second, recent factor is associated with doning and biomedicine, which are often perceived as threats to human dignity. ${ }^{5}$ Cearly, indignities can tell us much about dignity. Some even prefer to formulate the relation between dignity and indignity in terms of each other by saying that protesting against indignities is itself a feature of dignity and failure to protest against them is a feature of the absence of dignity. ${ }^{6}$

This paper will try to show, first, that the overwhelming success of the concept is surprising for the following reasons: many argue that there are actually two concepts rather than one; others, that it is an axiom without a basis or that it does not even exist; and all, that it possesses some utopian traits. Then, I will demonstrate that as a concept applied to both the living and the dead, it is productive in its own right and cardinal to historians.

The majority of writers studying human dignity distinguish between inherent human dignity, the inherent worth of the human being, and external human dignity, which is equated with worthiness of respect. I shall call this dassical view the 'double option'. In the double option, inherent human dignity is more important than external human dignity. The former is non-derogable and forms the infrastructure of the latter, which, in turn, can be derogated, violated, and lost, but which also constitutes the basis for human rights. The similarities are strong enough, though, to maintain that both types of dignity emanate from the same cluster of closely related phenomena. Within this general unity, the many differences are striking, as is shown in Table 1: 


\begin{tabular}{|c|c|}
\hline \multicolumn{2}{|c|}{ Human Dignity: The Double Option } \\
\hline inherent worth of human being & worthiness of respect of human being \\
\hline dimensions, attributes & attitudes, acts \\
\hline via intuition & $\begin{array}{l}\text { via observation of attitudes, acts, failures } \\
\text { to act }\end{array}$ \\
\hline $\begin{array}{l}\text { not scientifically provable; } \\
\text { phenomenological, metaphysical; } \\
\text { ascriptive }\end{array}$ & $\begin{array}{l}\text { scientifically discoverable; } \\
\text { empirical; } \\
\text { descriptive and prescriptive }\end{array}$ \\
\hline $\begin{array}{l}\text { universal } \\
\text { pre-societal }\end{array}$ & $\begin{array}{l}\text { contingent, person-, context-, and culture } \\
\text { dependent; } \\
\text { dependenton social relations }\end{array}$ \\
\hline \multicolumn{2}{|c|}{ entails self-respect } \\
\hline \multicolumn{2}{|c|}{ entails recognition respect ${ }^{8}$} \\
\hline indirect; via external dignity & $\begin{array}{l}\text { external dignity establishes } \\
\text { human rights; } \\
\text { establishes human rights; } \\
\text { is itself a human right or duster of } \\
\text { human rights; } \\
\text { constrains human rights, } \\
\text { establishes human duties. } \\
\text { fulfilment of human rights protects, } \\
\text { enhances dignity }\end{array}$ \\
\hline $\begin{array}{l}\text { inherent dignity can never be } \\
\text { derogated, violated, lost }\end{array}$ & $\begin{array}{l}\text { can violate or deny external } \\
\text { dignity of oneself or others; and } \\
\text { is reduced to instrument, } \\
\text { dehumanised }\end{array}$ \\
\hline
\end{tabular}

As the table shows, it is striking that the double conceptladks the darity and sharpness of a single concept. On doser inspection, the table reveals two additional sources of confusion. First, the descriptions for epistemology, method, scope, and human-rights violations are not simply divergent for both types of dignity; they are also contrasted or even mutually exdusive. Second, theexact re lationship between dignity and human rights seems to be a major riddle. It is not dear whether (a) human rights or (b) human rights are founded on human dignity or whether (c) dignity is itself a human right or a cluster of human rights, or (d) constrains human rights and establishes human duties. Most adhere to position (a), although some hesitate in choosing between (a) and (b). Even in the Universal Dedaration this confusion persists. Dignity is mentioned in the preamble and in Article 1 as the foundation of all human rights, but when referred to in Articles 22 and 23, 
it is explicitly associated with economic, social, and cultural rights and linked to the right to a just remuneration ensuring "an existence worthy of human dignity". This is illogical for two reasons: first, the priority of economic, social, and cultural rights is against the United Nations view of the indivisibility of human rights; second, when the realisation of those rights is at odds with the realisation of political and civil rights and brings into conflict two forms of dignity with oneanother ('full bellies' versus 'free minds'), current insights favour a different view: that with their political rights respected, citizens will participatemorefullyin the economic development of their society. ${ }^{9}$ Be that as it may, the Universal Declaration seems to include both positions (a) and (b).

Regarding conception (c) it has been said that there is no such thing as "a right to dignity". As long as external dignity is linked to inherent dignity (in the doubleoption it is), theemphasis is less on its quality as a value or a right than on its supposedly ontological character.$^{10}$ However, it is correct to say that everyone has a right to respect for one's dignity. A discussion of conception (c) is notcompleteif it does not deal with the relation between dignity, honour and reputation. Pre-1945 texts such as 1907 Hague Regulations or the 1929 Geneva Conventions do not mention the term "dignity", although they occasionally refer to "honour". ${ }^{11}$ Honour and reputation are basic human rights meriting high protection levels and figuring prominently in the Universal Declaration. ${ }^{12}$ In what is undoubtedly a remnant of the historical use of the concept of dignity evoked at the outset, numerous national constitutions refer to honour and dignity in the same breath; some even seem to interpret them synonymously. If they do, they adopt position (c) and narrow the concept of dignity to one human right related to the personality of human beings. For position (d), dignity is not seen as empowerment but as constraint, limiting permissible actions and reducing freedom..$^{13}$ This perspective is different from (a) in that it emphasises that we have to accept limits and duties in order for the dignity and human rights of others and oneself to flourish.

A few authors reject the double option. In 1996, J ohn Coetzee (the 2003 Nobel Laureate in Literature) defended a zero option:

For Coetzee, human dignity does not exist, and if it does, only in the sense of a construct it is a foundational fiction and its inextricable counterpart - respect- is superfluous. For him, it is real 
only in the sense that human beings take the fiction seriously and act upon it. For being fictional, Coetzee's dignity is remarkably dynamic: it does not exist, but infringements of it do; it does not exist, but it could well be extended to all living creatures in the future. The zero option raises two crucial questions: Does human dignity exist at all? To what extent is it utopian?

The first of thesequestions is examined in Table2, which summarises what authors think about the basis of human dignity. It appears that there is notonly no consensus about this basis, but also that the positions taken are bluntly contradictory. In itself, this is a sign that the concept is problematic.

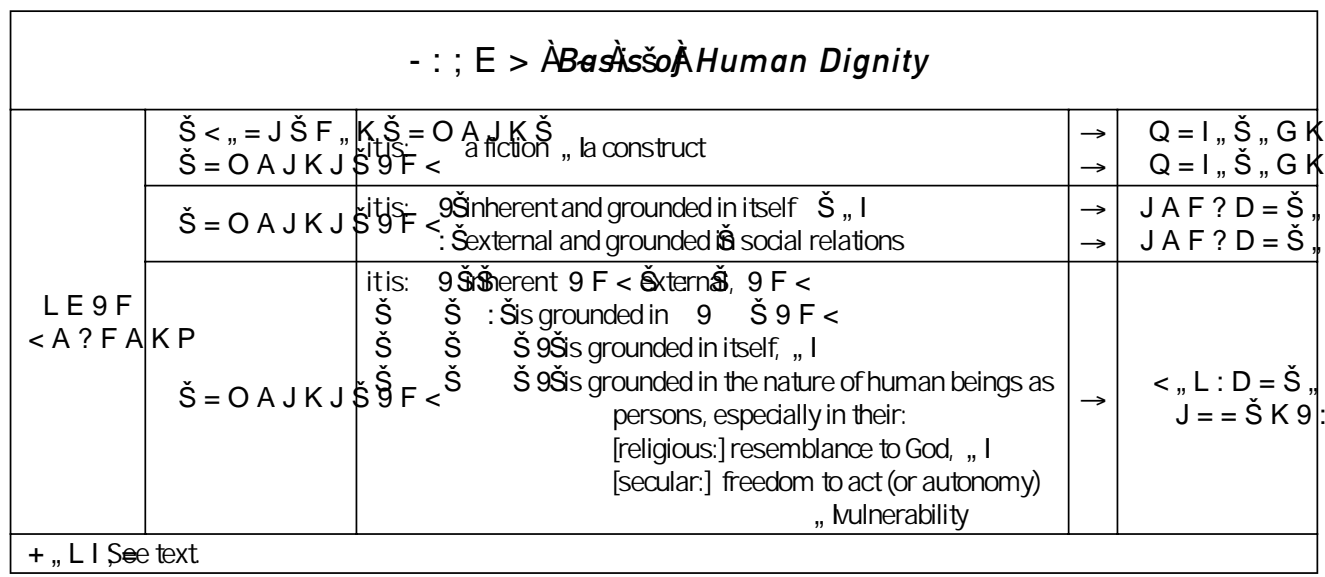

If we exclude the "do not know/ no answer" possibility, there are three basic options: zero, single, and double. It is not easy to distribute authors over these options. Similar to Coetzee, Abraham Edel defends the view that the concept is an ethical construct designed to catch and explain phenomena less well explained without it. ${ }^{15}$ Others think that human dignity is a single concept which is based on itself or that it does exist because human beings live together. Most of those who think that dignity exists as a single phenomenon interpret it as external. For J oel Feinberg, human dignity is not grounded in anything more ultimate than itself; it is a circular concept: human dignity is based on humanity, but it is unclear what it is about our humanity that gives it dignity. For him, human dignity expresses an attitude of respect towards the humanity in each person. ${ }^{16}$ Many of those advocating the double option agree that the basis for human dignity is the nature of human beings as persons. Furthermore, religious and secular approaches can be distinguished from one another. I shall comment here only briefly on the (hesitantly) secular version as it appears in the work of its most influential representative, Immanuel Kant. ${ }^{17}$

Kant maintained that when human beings are moral, they follow the categorical imperative. He gave several (compatible) definitions of this categorical imperative, but the one that interests us here tells us that when human beings are moral, they consider other human beings as ends in themselves and, in doing so, assign human dignity to them. For Kant, the source of the capacity to be moral and to follow the categorical imperative, in short the source of dignity, was the autonomy of the will of human beings (or their freedom).$^{18}$ Following Kant, some prodaim the 
autonomy and freedom of rational human beings to be more adequate concepts than dignity. Some categories of human beings, however, are not free or autonomous in the Kantian sense: I am referring neither to prisoners nor to those who abuse their freedom to inflict indignities on themselves, but to categories such as young children, the mentallyill, and the irreversibly comatose. Does the fact that these categories are notfree in the Kantian sense of 'autonomous' mean that they do not possess dignity? Although notfreeas adults or rational human beings, they possess dignity because they are human beings. Some even contend that human dignity is most visible exactly where circumstances of vilnerability, not autonomy, prevail. ${ }^{19}$ The nobility widely ascribed to victims subjected to extreme humiliating treatment is evidence for this thesis. In addition, if freedom causes human dignity, as Kant maintained, it is equally true that, as we saw, human dignity properly understood may limit rather than enhance freedom.

Most human-rights instruments adhere to the single or double option. Regarding national constitutions, it is difficult to group them according to their exact position. Given that 75 per cent of the world's national constitutions use the concept of human dignity, that many of the remaining 25 per cent imply it, and that only a few do not give thought to the concept, it is safe to say that the zero option is rare among them. Constitutions, however, do not dearly distinguish between inherent and external human dignity: perhaps most surprising is that they use the language of inherent human dignity as much as the language of external human dignity. Undoubtedly, the solemn genre invites solemn wording. All options - zero, single, double - are, I think, legitimate positions. To borrow W. B. Gallie's expression, human dignity is an "essentially contested concept". This means that it is impossible to find a general principle for deciding which of the uses of "dignity" is the best, and, therefore, whether dignity exists at all. Of the three options, however, the double option is shared most by far. The conviction that it does not exist is not popular.

Let us now look at the second question: to what extent is dignity utopian? Before approaching this question, I should recall that in 1961 the philosopher Ernst Bloch compared the doctrines of natural law and social utopia. For Bloch, natural law is a child of the Enlightenment, an optimistic philosophy contrasting dignity and humiliation, whereas social utopian thought is a child of the early Industrial Revolution, a pessimistic narrative contrasting misery and happiness. Both have in common that they are dreams: their projects aspire to change the social structure in the hope of detecting a better life and a better world beyond it Aboveall, natural law and social utopia unavoidably meet and need each other because no real dignity can exist without the elimination of misery, and no real happiness without the elimination of submission. ${ }^{20}$ From Bloch's comparison, we conclude that there exists some common ground between dignity and utopia and that it is located above all in the link and tension, al ready noticed, between free minds and full bellies. If, inspired by Bloch, we now ask to which extent dignity is utopian, an impressionistic approach is not sufficient because, at first glance, the parallels between utopia and dignity seem arbitrary. Thus, there is a parallel between utopia and the zero option of dignity, because as products of the fantasy of the human mind both exert influence only insofar as human beings act upon those fantasies. There is also a parallel between utopia and the double option of dignity, for a society in which human dignity and human rights are completely realised is an ideal society. We clearly need more analysis to give less ambiguous answers. 
Table 3tests the dignity conceptagainsta list of characteristics of utopia. On inspection, both inherent and external human dignityarise as conditions which are mainly, but notentirely, anti-utopian. Inherent human dignityshares some of the characteristics of utopia (seetable descriptions for epistemology, method, means, and scope), which give it a utopian ring. Three of these table descriptions are the same as those in Table 1 for which inherent and external human dignity differedmost. External human dignity or respect itself has two sides indeed: a descriptiveside, which is anti-utopian, and a prescriptive side with a utopian element Dignity is not only and not al ways a reality; it is as much an aspiration, a desired state of affairs, a dream to be realised. On balance, the case for speaking of human dignityas an undiluted utopian concept is notvery convincing, even though both types of dignity decidedly have utopian edhoes. The crux of the difference summing it all up is that utopia embraces and dignity

. Expressed in Karl Popper's subtle and deceptively simple words: " $T$ There is, from the ethical point of view, no symmetry between suffering and happiness, or between pain and pleasure... Instead of the greatest happiness for the greatestnumber, one should demand, more modestly, the least amount of avoidable suffering for all. ${ }^{21}$ This is, I think, the difference between utopia and dignity in a nutshell.

A secondary argument against the utopian character of human dignity consists in the fact that it is a concept with multiple authors. The crucial role of Kant and of perspicacious jurists such as René Cassin and J ohn Humphrey, both authors of early drafts of the Universal Declaration (for which the former received a Nobel Peace Prize in 1968), should not be underestimated. The concept, however, has, on the whole, many parents, in sharp contrast to most utopias that are linked to the names of their inventors: Plato, Thomas Münzer, Thomas More (who coined the term "utopia"), Karl Marx, to name a few. When a concept has many authors, the chance that it is the utopian fantasy of one mind becomes smaller.

It would be easy to conclude from this discussion that human dignity, if such a thing exists, is a dragon with multiple heads, or indeed a majesty with short legs needing pillows for support. That would be true. It is equally true that it is a principle successfully trying to catch the essential feature of human beings. 


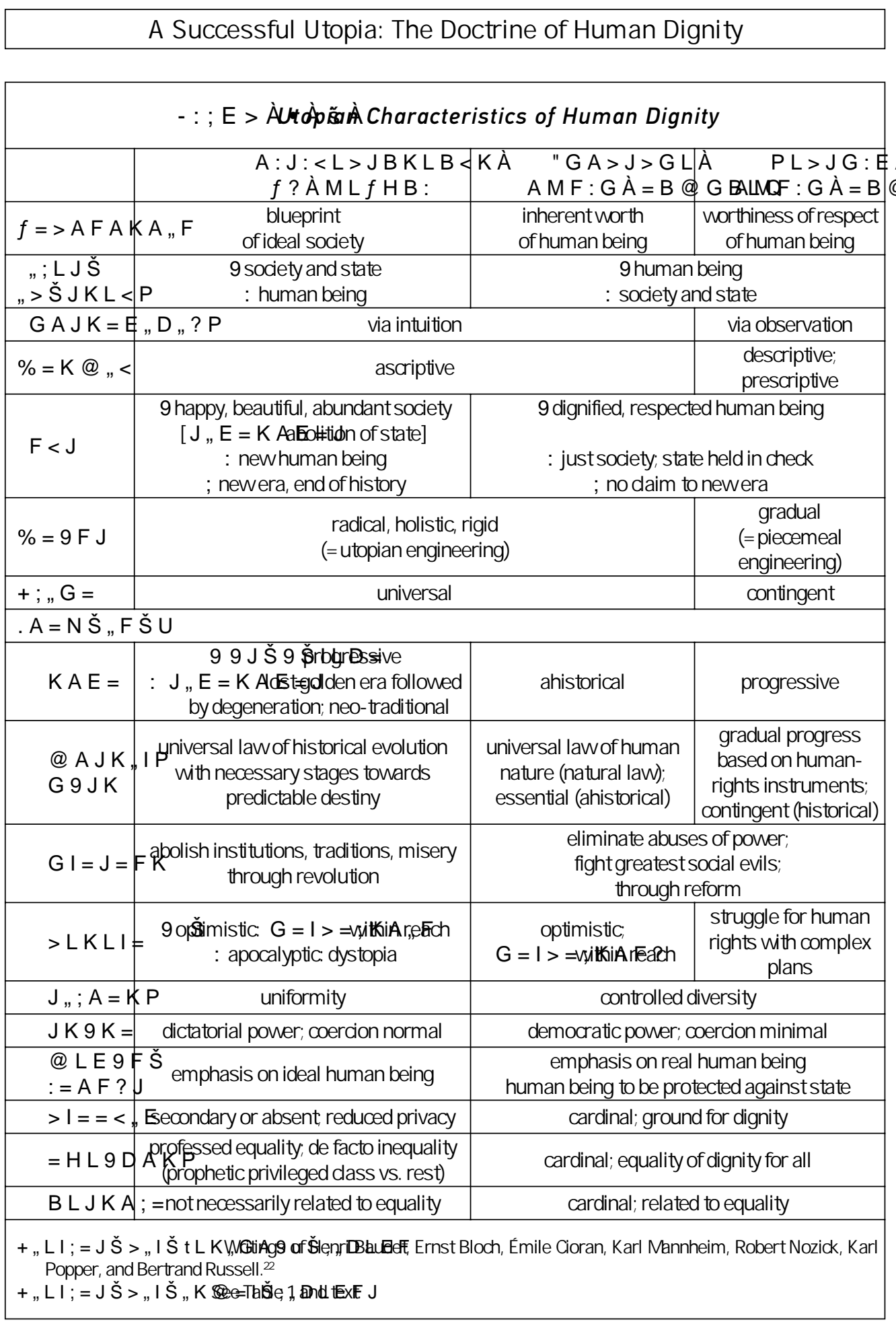


I will demonstrate now that the theoretical discussion about dignity has important bearings on practical matters, in courts as well as among historians. If we claim that human dignity is the foundation of human rights and that thinking about human rights is nothing but an attempt to render the concept of human dignity operational, it should be feasible to compile a list of concrete examples of dignity. The most widely accepted of these lists is the Universal Declaration of 1948. The opposite has to be true too: if we are able to compile a list of examples of dignity, we should al so be able to compilea list of examples of indignity. The most famous of these lists is to be found in the four Geneva Conventions of 1949 (supplemented with two Additional Protocols in 1977) regarding the humane treatment of civilians and prisoners in times of war. Ratified by all countries in the world except Nauru (population 12,000) and therefore major sources of international humanitarian law, they explicitly inspired the definitions of war crimes adopted by the International Criminal Court (established in 2002). This is what the commentaries of the Red Cross (the official custodian of the Geneva Conventions) tell us about the concepts of humane and inhumane treatment - and hence, about dignity and indignity.

It is safer, we are told, to specify indignity than dignity itself, but even then we should see to it carefully that a list of outrages is not abused. Table 4 attempts to present such a list; it summarises those crucial articles of the Statute of the International Criminal Court (and, by implication, of its pedestal, the Geneva Conventions) covering "outrages upon personal dignity". An "outrage" should be understood as the intentional infliction of emotional distress; an "outrage upon personal dignity" as humiliating and degrading treatment of persons. 


\section{Outrages upon Personal Dignity}

* murder, extermination

* enslavement

* enforced disappearance

* apartheid

* deportation

* unlawful imprisonment
* persecution against identifiable groups

* torture, mutilation

* rape, sexual slavery, enforced prostitution, forced pregnancy, enforced sterilisation

* biological experiments

* non-consensual medical or scientific experiments

* outrages upon the dignity of dead persons

* outrages upon the dignity of persons unaware of the humiliation involved (unconscious persons and the mentally disabled)

* invasion of privacy

* defamation

* poverty and hunger

\section{tions (1949) and their Protocols (1977). ${ }^{25}$ \\ Assembly of States Parties to the Rome Statute of the International Criminal Court, \\ (2002); ${ }^{26}$ based on the Geneva Conventions (1949) and their Protocols (1977). ${ }^{27}$ \\ Universal Dedaration of Human Rights (1948). ${ }^{28}$}

Rome Statute of the International Criminal Court (1998),24 based, inter alia, on the Geneva Conven-

If the internal logic of Table 4 is not immediately transparent, it is because the thinking about the concept of "outrage upon personal dignity"'is in plain evolution. The core texts used for thetable do not al ways distinguish the same crimes, nor list them under the same categories, nor give them the same names. For example, the Geneva Conventions speak of "outrages upon personal dignity, in particular humiliating and degrading treatment" without specifications, but the Additional Protocols subsume such practices as rape and enforced prostitution, or apartheid and racial discrimination, under the heading of "outrages upon personal dignity" in some places, while in others they list them separately. To understand Table 4, then, one should follow a two-step strategy. First, as the quotation already indicated, the starting point of the Geneva Conventions is the duty to treat civilians and prisoners humanely and respectfully in times of war. Time and again, they describe the correct treatment as "humane treatment" and "respect for persons".29 Both expressions are valid synonyms for what we have called external human dignity, defined as "worthiness of respect" in Table 1. Second, the opposite of "humanetreatment" and "respect for persons" consists of two groups of acts. The first group in Table 4 contains the three capital crimes: genocide (the ultimate violence against national, ethnical, racial or religious groups), crimes against humanity (always committed as part of a widespread or systematic attack against civilian populations), and war crimes (occurring in international and internal armedconflicts). They imply outrages upon personal dignity, as these outrages are a structural part of them. ${ }^{30}$ The very name "crimes against "was chosen because such crimes involve conduct offending humanity itself. The second group in Table 4, consisting of the war crime of outrages upon dignity proper, 
designates such outrages degree as to be when the severity of the humiliation or degradation was to such a as an outrage upon personal dignity - taking into account relevant aspects of the cultural background of the victim.13

Can the outrages listed in Table 4 serve as a list of indignities generally? Table 4 does not represent a negative blueprint of the complete Universal Declaration, but only reflects some of the worst violations upon human dignity. The Universal Dedaration is not a perfect mirror of the concept of human dignity; Table 4 is even less a perfect mirror of the concept of outrages upon personal dignity. list of indignities contains many of the outrages in Table 4; any list aspiring to exhaustiveness should contain them all.

Table 4 offers other lessons as well. The 1998 Rome Statute of the International Criminal Court determined that so-called Elements of Crimes should bedrafted for the capital crimes over which the Court has jurisdiction (genocide, crimes against humanity, and war crimes) in order to assist it in the interpretation and application of the definitions of these crimes. After much preparatory work, the Assembly of States Parties to the Rome Statute adopted these Elements of Crimes in 2002. They included Elements for war crimes, among them the "war crime of outrages upon personal dignity". The first Element for this particular war crime reads: "The perpetrator humiliated, degraded or otherwise violated the dignity of one or more persons." A noteattached to this Element adds: 'For this crime, 'persons' can indude dead persons. It is understood that the victim need not personally be aware of the existence of the humiliation or degradation or other violation."In this way, a new concept - outrages upon the dignity of dead persons - was forged. In 2003, Knut Dörmann, a legal advisor of the International Committee of the Red Cross who commented on this Element, explained that "outrages upon the dignity of dead persons" included the mutilation of dead bodies and refusal of a decent burial. ${ }^{32}$

This attemptat defining the Elements of the crime of "outrages upon personal dignity"represents an important development for historians. A demonstration of the reason why this is so important should start with the difficult issue of whether the concepts of human beings and persons include the dead. The Conventions and the Court affirm this viewpoint, because they speak of "dead persons". Philosophically, though, the viewpoint of the Conventions and the Court is not solid. ${ }^{33}$ The dead are human beings (or persons) but human beings (or persons). ${ }^{34}$ Moreover, their assertion that the dead, as persons, can be submitted to outrages, i.e. that they are capable of suffering humiliation, is untenable. It is not the dead who suffer the humiliation - for the dead do not suffer anything - but their surviving dear and near. It follows that the dignity to be conferred upon the dead is not human dignity, but

dignity is an appeal to respect the actual humanity of the living and the very foundation of their human rights. dignity is an appeal to respect the past humanity of the dead and the very foundation of the duties of the living towards the dead.

A host of facts proves that this new concept of posthumous dignity exists. One of the most corroborated facts within anthropological research is that the living almost universally do respect the dead and believe that the latter have dignity. Archaeologists consider traces of funerary rites in a certain territory as very powerful proof of - indeed as virtually equivalent to - the presence of hu- 
man activity there. The search for remains of fallen soldiers or victims of disasters, often costly and time-consuming, is explicable only by some conception of dignity. On various occasions, the almost universally ratified Geneva Conventions stress that the remains of persons should be re spected. International regulations and conventions have emphasised this point at least since the nineteenth century. Not surprisingly, posthumous restoration of the dignity of deceased victims of serious human-rights abuses has been a powerful motive behind the establishment of the International Criminal Court Paradoxically, even the punishment of dead bodies is proof of thefact that posthumous dignity exists. Belief in theimpossible- that theliving can punish the dead - indicates that the perpetrators perceive dead bodies as more than things. And the fact that the living feel deeply offended by posthumous punishmentmeans that human remains possess symbolic value. Negledting the view that the dead possess dignity offends the sensibilities of humanity at large. I condude that the dead do not possess human dignity- as the tacitly suppose - but posthumous dignity, and that, therefore, they too deserve respect.

If we accept this conclusion, questions reminiscent of our discussion of human dignity emerge. First, it remains obscure how exactly posthumous dignity exists: some believe that it is inalienable and recognised as such by the living, others that it is actively attributed to the dead by the living. Perhaps both conceptions - inherent and external posthumous dignity- are true in that the dead possess potential dignity that is activated each time the living come into contact with them. Furthermore, violations of posthumous dignityalso represent dangers for historians. Quite a number of laws contain provisions for "protection of the memory of the dead" and "defamation of the dead". When abused (and they often are), such laws have a chilling effect on the expression and exchange of historical ideas and are often only barely veiled attempts at censorship. Confronted with this problem, historians should proceed responsibly.

$*$

The concept of human dignity has serious flaws. It is confusing and controversial. Moreover, it is partly utopian. There seems to be, though, no better alternative to speak about the humanity of living persons. The times in which certain characteristics of human beings were called "sacred" are gone. The idea of the sanctity of life itself, however, has not dissipated in secular times. The concept of human dignity is preferable not only because there seems to be no better alternative; it is also a productive concept in its own right. First, it spawned a body of human rights. This led to the gradual establishment of a system of declarations, conventions, protocols, and courts - a trend that will continue. Second, the concept permitted the international community to draft a list of outrages upon personal dignity, to identify the worst of these outrages as genocide, crimes against humanity or war crimes, and, increasingly, to prosecute their perpetrators. Third, the structure of the concept - especially its close correspondence with the twin concept of respect - provideda point of departure for the complementary concept of posthumous dignity that yields a proper perspective to speak about the dead. And, following Coetzee, it is possibleto leave speciesism behindand to maintain that living creatures other than human beings possess some form of dignity and even thatnon-living creatures (likethe dead) and objects (likenature) areendowed 
with dignity, provided that these new types of dignity- which entail duties on the part of human beings - are not mistaken for human dignity. Historians should welcomethe concepts of human and posthumous dignityas a foundation for their duties. At the sametime, they should be on the alert that they can be censored in the name of dignity. We all know that most utopias in history, whether backward- or forwarc-looking, failed when the doctrines informing them were tested in reality. While being tested, many produced terror rather than paradise. Human dignity, insofar as it is utopian, is an exception. It will not lead us to paradise, but it is an increasingly successful attempt to prevent us from seeking a destiny in terror. It is a pragmatic utopia.

The abridged version of this essay - an address to the 20th International Congress of Historical Sciences in Sydney - was published as "How Humanity Stands on its Dignity", (13) uly 2005), p. 36. All websites mentioned in this essay were last visited on 22 December 2006.

Ryszard Kapuściński, ,San Diego: Harcourt, Brace, J ovanovich, 1983, p. 27.

All constitutions found on: http:/ / www.constitution.org; http:/ / www.oefre.unibe.ch/ law/ id; http:/ / www.psr.keele.ac.uk, among others. Out of 193 constitutions, 145 (75.1 per cent) contain the concept, most of them in a prominent place (survey date: April 2004).

Bernard Edelman, "La Dignité de la personne humaine, un concept nouveau", Paris: Receuil Dalloz, 1997, , p. 186.

See the United Nations Declaration on Human đoning, and the UNESCO dedarations on the human genome, on human genetic data, and on bioethics.

See, for example, Ronald Dworkin, , New York: Knopf, 1993, pp. 234-5.

Most coherently formulated in Herbert Spiegelberg, "Human Dignity. A Challenge to Contemporary Philosophy', in: Rubin Gotesky and Ervin Laszlo (eds), , New York: Gordon and Breach, 1970, pp. 53-61, and Alan Gewirth, "Human Dignity as the Basis of Rights", in Michael J . Meyer and William A. Parent (eds), , Ithaca: Cornell University Press, 1992, pp. 10-28.

Stephen Darwall distinguishes recognition respect (an attitude restricting the class of morally permissible actions) from appraisal respect (respect for merit) in "Two Kinds of Respect", (1977), pp. 36-49.

SeeAntoon De Baets, "History of Human Rights", in: Neil J . Smelser and Paul B. Baltes (eds), , vol. 10, Oxford: Elsevier, 2001, p. 7015.

David Feldman, "Human Dignity as a Legal Value - partl", 44 (1999), pp. 682, 687, 697.

(1907), Article 46, and 
Committee of the Red Cross,

(http:/ / www.ohchr.org; 1948), Article 12. Seealso International 202 (http:/ / www.icrc.org; Geneva, s.d.).

and

Feldman, "Human Dignity - part I", pp. 685-686, 699-702 and 'Human Dignity as a Legal Value - part II", $\quad 45$ (2000), p. 75; J ack Donnelly, "Human Rights and Human Dignity: An Analytic Critique of Non-Western Conceptions of Human Rights", 76:2 (1982), pp. 303, 306; J acob D. Rentdorff and Peter Kemp (eds), vol. 1, Beyleveld and Roger Brownsword, ,Copenhagen and Barcelona, 2000, ; Deryck 29-47. , Oxford: OxfordUP, 2001, pp.

J ohn M. Coetzee, , Chicago: University of Chicago Press, 1996, pp. 14-15.

Abraham Edel, 'Humanist Ethics and the Meaning of Human Dignity', in: Paul Kurt (ed.), ,Englewood Ciffs, NJ : Prentice-Hall, 1969, pp. 232-40; also Spiegelberg, 'Human Dignity', p. 52 (where he discusses Edel).

J oel Feinberg, , Englewood diffs, N.J. .: Prentice-Hall, 1973, pp. 88-94; see also Feldman, "Human Dignity- part I", 687; Arnold Toynbee, "Traditional Attitudes towards Death", in: Idem et al., , London: Hodder \& Stoughton, 1968, pp. 59-64 ('The sense of human dignity.")

Immanuel Kant,

(1785), in:

, vol. 4, Berlin: Preußische Akademie der Wissenschaften, 1903, pp. 436, 438, 440. For an attack on Kant's notion of human dignity, seeJ oel Feinberg, 94-7. , New York and Oxford: Oxford UP, 1986, pp.

Kant, , pp. 455-63.

Rendtorff and Kemp, Useless Concept", , vol. 1, pp. 31, 50-51, 397-98. Ruth Macklin ('Dignity is a for autonomy. 327 [2003], pp. 1419-20) equates dignity solely with respect

Ernst Bloch, 'Sozialutopie und Naturrecht', in: Idem, ,Frankfurtam Main: Suhrkamp, 1977 (1961), pp. 233-8.

Karl Popper, , vol. 1, London: Routledge, 1966 (1945), pp. 284-5, n. 2.

Henri Baudet, , New Haven: Yale UP, 1965 (1959), pp. 32-42; Bloch, “Sozialutopie und Naturrecht”, pp. 233-8; Émile Goran, , Paris: Gallimard, 1960, pp. 42, 109-111, 117; Karl Mannheim,

pp. 173-236; Robert Nozick, Popper, $\quad$,157-68; Idem, 1957; Karl Popper, "Utopia and Violence" (1947), in: Idem, , Londonand New York: Routledge \& Kegan Paul 1991 (1929), ,London: Routledge \&Kegan Paul, 1974 (1963), pp. 355-63; Bertrand Russell, , New York: Basic Books, 1974, pp. 326-34; Karl , London; Routledge \& Kegan Paul, 
, London: Allen \& Unwin, 1946, pp. 129-40, 538-43. Mannheim defines as utopian "[o]nly those orientations transcending reality.... which, when they pass over into conduct, tend to shatter, either partially or wholly, the order of things prevailing at the time"'(p. 173). If utopian at all, human dignity corresponds best with his "liberal-humanitarian utopia" (pp. 197-206, especially 198, 200).

International Committee of the Red Cross, , 53-54.

International Criminal Court, (http:// www.icc-cpi.int; Rome 1998), Articles 6, 7, 8, especially 8(2)(b)(xxi) and 8(2)(c)(ii). For comments on the crucial Article 8(2)(b)(xxi) [outrages upon personal dignity], see Knut Dörmann,

2003, pp. 314-24, 404-5.

, Cambridge: Cambridge UP,

(1949), Common Article3; ,Article 14; ,Article27;

(1977), ,

Articles 11, 75, 85; ,Article 4. See also , Article 52, ,Articles 31, 32, 95; , 144-45, , 201.

Assembly of States Parties to the Rome Statute of the International Criminal Court, (http:// www.icc-cpi.int; New York, 2002), "Elements of Crimes", 140, 146.

,Articles 15-17; , Article 20; , Article 120; ,Articles 129-30;

, Artides 32-34; , Article 8.

, Articles 12, 22, 23.

International Committee of the Red Cross, , 201.

Dörmann, , pp. 323-24.

Ibid., pp. 318-19.

Ibid., pp. 314-15, 323.

Seealso Albin Eser, “Mental Elements - Mistake of Factand Mistake of Law”, in: Antonio Cassese, Paola Gaeta andJ ohn R. W. D. J ones (eds),

, vol. 1, Oxford: Oxford UP, 2002, p. 923, n. 156.

In the remainder of the essay, I summarise the reasoning of Antoon De Baets, "A Declaration of the Responsibilities of Present Generations toward Past Generations", 43 (2004), pp. 133-39, 157-58. See also Idem, "Postumestraffen"[Posthumous Punishment], 39:170 (March 2006), pp. 47-60. 